\title{
Glass Ionomer Cement Incorporated Nano- Hydroxyapatite-Silica: The Road towards Improvement
}

\author{
Norhayati Luddin* \\ Department of Restorative Dentistry, School of Dental Sciences, Universiti Sains Malaysia, Malaysia
}

*Corresponding author: Norhayati Luddin, Associate Professor and Consultant Prosthodontist, Department of Restorative Dentistry, School of Dental Sciences, Universiti Sains Malaysia, Health Campus, 16150, Kubang Kerian, Kelantan, Malaysia

Submission: 眥 February 21, 2018; Published: 眥 February 27, 2018

\section{Editorial}

Up till today, no dental material seems to have ideal properties for any dental application. For that, researchers and manufacturers seem to never lose hope in developing the technique, modification and/or formulations that aims to improve the properties of these materials to its possible best. Among the most widely used materials in restorative dentistry is Glass Ionomer Cements (GICs). Their use has been popular due to their unique properties that adhere directly to the tooth structure and base metals [1], exhibit longterm fluoride release [2] and possess good biocompatibility [3]. Despite having those properties, their drawbacks like brittleness, poor abrasion resistance and low flexural and tensile strengths limits their application for use in high stress bearing areas, such as on the posterior teeth. As such, several modifications have been introduced to the conventional GICs. These include the addition of titanium dioxide, hydroxyapatite, glass fibre and bioactive glass, with the aim to improve the mechanical and physical properties of GICs [4-8].

These days, the application of nano-sized particles for biomaterials is becoming highly popular in dentistry. This nanotechnology involves the use of materials which has the size in the range of $1-100 \mathrm{~nm}$. Recent studies have suggested that the incorporation of nano-sized particles or "nanoclusters" can improve the mechanical properties of GIC $[6,9,10]$.

In particular, a few studies have been carried out to incorporate nano-hydroxyapatite-silica (nano-HA-silica) powders into conventional GICs (Fuji IX GP, GC International, Japan) $[9,11,12]$. It was found that the addition of nano-HA-silica into conventional GIC increased the material hardness by $73 \%$ [9]. The increase is believed to be associated with filling of voids between the hexagonal HA particles with nano silica particles. As a subsequent, it enhanced the material packing density thus increase its hardness. Further study supported this belief after carrying out Transmisssion Electron Microscope (TEM) and Scanning Electron Microscope (SEM) investigations. Both type of micrographs revealed good distributions of elongated HA and spherical silica within the specimen, with both of them were in nano-sized particles [11]. On top of that, this material had recently undergone further investigation to assess its cytotoxicity upon being treated with Dental Pulp Stem Cells (DPSCs). It was demonstrated that nano-HAsilica GIC exhibited favourable and comparable cell viability similar to conventional GIC, with the cells placed on each material showed good spindle morphology. In contrast, resin-modified GIC showed significantly lower cell viability compared to nano-HA-silica and conventional GIC [12].

Based on the results of these studies, we can conclude that nanoHA-silica GIC showed favourable findings in terms of mechanical and biological properties and thus can be considered as a future potential restorative material for use in clinical dentistry.

\section{Acknowledgement}

The studies on nano-HA-silica GIC were supported by Ministry of Higher Education of Malaysia under Fundamental Research Grant Scheme (FRGS): 203/PPSG/6171138 and 203/PPSG/6171173.

\section{References}

1. Craig RG (1997) Testing of dental materials and biomechanics. In: Craig RG (Ed.), Restorative dental materials. $\left(10^{\text {th }}\right.$ edn), Year book, Inc. St. Louis, MO: Mosby, USA, pp. 83-107.

2. Kent BE, Lewis BG, Wilson AD (1979) Glass ionomer cement formulations: The preparation of novel fluoroaluminosilicate glasses high in fluorine. J Dent Res 58(6): 1607-1619.

3. Ahmed HM, Omar NS, Luddin N, Saini R, Saini D (2011) Cytotoxicity evaluation of a new fast set highly viscous conventional glass ionomer cement with 1929 fibroblast cell line. J Conserv Dent 14(4): 406-408.

4. Elaska SE, Hamouda IM, Swain MV (2011) Titanium dioxide nanoparticles addition to a conventional glass-ionomer dental cements: Influence on physical and antibacterial properties. J Dent 39(9): 589-598.

5. Arita K, Yamamoto A, Shinonaga Y, Harada K, Abe Y, et al. (2011) Hydroxyapatite particle characteristics influence the enhancement of the mechanical and chemical properties of conventional restorative glass ionomer cement. Dent Mater J 30(5): 672-683. 
6. Moshaverinia A, Ansari S, Moshaverinia M, Roohpour N, Darr JA, et al. (2008) Effects of incorporation of hydroxyapatite and fluoroapatite nanobioceramics into conventional glass ionomer cements (GIC). Acta Biomater 4(2): 432-440.

7. Lohbauer U, Walker J, Nikolaenko S, Werner J, Clare A, et al. (2003) Reactive fibre reinforced glass ionomer cements. Biomaterials 24(17): 2901-2907.

8. Yli-Urpo H, Lassila LV, Narhi T, Vallittu PK (2005) Compressive strength and surface characterization of glass ionomer cements modified by particles of bioactive glass. Dent Mater 21(3): 201-209.

9. Rahman IA, Masudi SM, Luddin N, Shiekh RA (2014) One-pot synthesis of hydroxyapatite-silica nanopowder composite for hardness enhancement of glass ionomer cement (GIC). Bull Mater Sci 37(2): 213-219.

\section{For possible submission use the below is the URL Submit Article}

10. Luddin $N$ (2015) Incorporation of hydroxyapatite-silica nano-powder for enhancement of glass ionomer cement (GIC). J Interdiscipl Med Dent Sci 3(5): e104

11. Shiekh RA, Ab Rahman I, Masudi SM, Luddin N (2014) Modification of glass ionomer cement by incorporating hydroxyapatite-silica nanopowder composite: Sol-gel synthesis and characterization. Ceram Int 40(2): 3165-3170.

12. Noorani TY, Luddin N, Rahman IA, Masudi SM (2017) In vitro cytotoxicity evaluation of novel nano-hydroxyapatite-silica incorporated glass ionomer cement. J Clin Diagn Res 11(4): 105-109.

Your subsequent submission with Crimson Publishers will attain the below benefits

- High-level peer review and editorial services

- Freely accessible online immediately upon publication

- Authors retain the copyright to their work

- Licensing it under a Creative Commons license

- Visibility through different online platforms

- Global attainment for your research

- Article availability in different formats (Pdf, E-pub, Full Text)

- Endless customer service

- Reasonable Membership services

- Reprints availability upon request

- One step article tracking system 